\title{
Cultural Values Defining Turkish Nation: From the Perspectives of History Teachers ${ }^{1}$
}

\section{Mevlüt Gündüz}

Süleyman Demirel University, Faculty of Education, Turkey, mevlutgunduz@sdu.edu.tr

\section{Vedat Aktepe}

Nevşehir Hacı Bektaşi Veli University, Faculty of Education, Turkey vedataktepe@nevsehir.edu.tr

\section{Süleyman Erkam Sulak}

Ordu Üniversitesi, Faculty of Education, Turkey, erkamsulak@gmail.com

\section{Zuhal Başpinar}

Süleyman Demirel University, Faculty of Education, Turkey, zuhalbaspinar@sdu.edu.tr

\section{Ayșegül Büyükkarci}

Süleyman Demirel University, Faculty of Education, Turkey, aysegulbuyukkarci@sdu.edu.tr

This study, which aims to identify what values are significant for history teacher in teaching Turkish culture, was conducted based on qualitative research methods. Within this study, face to face interviews were done with 19 history teachers who serve in Isparta. According to data which was analyzed through content analysis and descriptive analysis techniques, participants mainly emphasized the values of patriotism, flag, and independence. Especially the terrorist incidents in recent times are thought to have had an impact on the opinions. Participants' perceptions of the concept of culture mostly focus on moral cultural elements. In response to the question of "Do the Turkish nation protect cultural values", it was found out that most of the teachers answered as "No". This finding can be regarded as universal values taking precedence over national values or our national values have deteriorated.

Keywords: cultural values, Turkish culture, teacher opinions, identity, history teachers

\footnotetext{
${ }^{1}$ The present study was presented as at $2^{\text {th }}$ The International Symposium on Education and Social Sciences in the Geography of Turkish at Gaziantep University on 5-7 May, 2016 and the abstract was published in the proceedings, then it was developed into a full article.

Citation: Gündüz, M., Aktepe, V., Sulak, S. E., Basppınar, Z., \& Büyükkarci, A. (2019). Cultural Values Defining Turkish Nation: From the Perspectives of History Teachers. International Journal of Instruction, 12(2), 193-208. https://doi.org/10.29333/iji.2019.12213a
} 


\section{INTRODUCTION}

The concept of culture, which has been defined through different contents in each society, has been studied in two dimensions; anthropological and sociological. In anthropological terms, culture can be defined as the skills, ideas and behaviours, which individuals acquire as a member of a society. There are both similarities and systematic differences in the definition of culture, as the skills, ideas and behaviours of the individuals within the society. From sociological perspective, the concept of culture covers the symbolical features of the social life. In other words, it refers to the life styles, the way they dress, ceremonies, work structures, and religious rituals of the members of a society or the groups within a society. In this context, according to Malinowski's definition, culture is a holistic sum of the tools and consumer goods, constitutional documents formed for various social groupings and ideas, skills, beliefs and traditions that are specific to humans (Yanık, 2013). These afore mentioned abstract and concrete elements are combined to form the basic features of a social culture. On the other hand, values are standards used to identify what is desired and what is not desired, what is good or bad, beautiful or ugly for the members of a culture. Values are the general principles, actually reflected on every area of the life style of the public (Macionis, 1989). In social life, everything is perceived and compared in accordance with values. Generally, every individual adopts the values of the society they live in, and uses these in different approaches and applications (Kincal, 2015). From this perspective, cultural values are considered as the whole of the major characteristic elements of every society.

A group of people sharing a common language, religion and civil authority structure, forming a linguistic, religious and political society respectively, creates a cultural society. Cultural societies may be in many different types. Some share no common features but the culture, while some share a common religion, especially if their culture is based on religion. Some are formed of an ethnic group. Actually, since every culture is the culture, creator and historical carrier of a group of people, every culture has an ethnic basis. However, these two can be separated. Ethnic societies can lose their traditional culture when they immigrate to another place or choose another culture (Parekh, 2002).

The culture, in which the individual was born and maintained their life, has a significant effect on shaping their sense of culture. The individual is a part of the culture they exist in, and the total value judgements of the individuals present the cultural values of their society. In earlier studies, culture is defined as "a structure studying and involving the habits, beliefs, art, ethics and law formation of the society" (Taylor, 1871) or "a collective programming of human thinking system that separates a society from another" (Hofstede, 1980) (cited in: Ercan \& Sığrn, 2015). However, when used single-handed, culture covers almost every part of human life. When used as an adjective, it about the area or side of human life, that is defined with that adjective. It is used for beliefs and traditions that supervise business culture, drug culture, ethical, political, academic and sexual culture concepts, interest areas of life, conceptualization, limitations, and organization styles. Concepts, such as homosexuality, youth, mass, working class culture 
define the places of these groups within the society and the way they conduct their internal and external affairs (Parekh, 2002). From this perspective, common thoughts, judgements and beliefs formed in relation to the redundancy of the common grounds related to the various activity fields within each society are also evaluated under the roof of the concept of "culture".

Economic, political and other institutions are also closely related with the culture that has a dynamic structure. No society can form first their culture then their institutions, or first their institution then culture. As culture shapes economic, political and other institutions, they shape the culture accordingly. They structure the world in their unique ways, limit the range of possible human acquisitions and relations, shape basic human experiences and deeply effect the context and content of culture (Granato, Inglehard \& Leblang, 1996; Parekh, 2002). From this point of view, democracy and politics culture of each country is different from each other, while adoption of liberal, capitalist or communist economy models reflects the economic culture of the society. Therefore, various social elements affect the cultures of societies (Smith, Peterson \& Schwartz, 2002).

Schawartz (1999), who states that there are 7 types of cultural values, claims that intellectual and affective autonomy versus conservatism; hierarchy versus egalitarianism; social harmony versus mastery elements lead the societies and cultural values gain existence with these mentioned conflicts. According to him, egalitarianism, intellectual and affective autonomy values are in the forefront of the cultures of western societies, while hierarchy, conservatism and mastery values are more dominant in eastern societies due to the effects of religious norms. These values reflect/are reflected in every area of life (economic, social, cultural, political) in various ways.

According to Kafesoğlu (1992), life and behaviour styles that differ one nation from another are shaped with the national culture. The languages, religions and traditions of nations are the cornerstones of the national cultures. What makes the difference between life and behaviour styles of an English and a Persian meaningful is the value judgements in their national cultures. If a Persian reacts in the same way with an English to certain events, it can be claimed that English culture affects Persian culture in some aspects (Mahiroğulları, 2005). Besides, many perceptions in a society, such as food, clothes, traditions, view of the world, philosophy of life, value hierarchy/priority; thoughts and behaviours are the national cultural elements of that society. According to Aydin (1986, cited in: Ulusoy, 2015), who states that personality structures of the members of a nation are shaped within the culture of that nation, the more a nation can reflect its own culture on the social values, the more it presents this culture to the generation on educational level, the more the members of that nation can find their own characteristics, and avoid the problem of alienation.

Additionally, the priority of some values in the culture of each society differs from the others. For instance, Robin Williams found in his research conducted in the USA that first five cultural values were; success, discipline, humanity, practicality and competency, self-development (Kincal, 2015). As is the case for every nation, there are also cultural values that show what is good or bad, what is beautiful or ugly, for what to 
live or die for Turkish nation. Tezcan (1974) splits Turkish cultural values into 6 as; family, educational, economic, religious, political and free time; and into two as positive and negative. According to his positive values for Turkish people are: "heroism, patriotism, valour, religiousness, austerity, sparing, commitment to soil, hospitality, respect, benevolentness, tolerance, dignity, seriousness, sedateness, modesty and cleanness", while the negative values are; "ignorance, cheating, cunning, aggressiveness, lasciviousness, uncleanliness (environmentally), superstitiousness, selfishness, laxity, resignation, religiousness (fanaticism), pride (in international affairs), laziness, treachery, vengefulness and cruelty" (cited in: Arslanoğlu, 2005). It can be seen here that cultural values are generally handed in moral and religious terms.

Transferring of all abstract/concrete elements defined as cultural values to next generation is important for the continuity of states, and preserving the unity and solidarity of the countries. Transferring of culture, which is one of the fundamental missions of educational institutions, is included in-disciple attainments of social sciences lesson in primary schools, and history lesson in secondary and high schools. Moral, cultural and social values are transferred to students in history lessons, and teachers try to teach student why they should protect these values through past phenomena/events (Ulusoy \& Dilmaç, 2005). Accordingly, revealing the exact perspectives of fundamental values defining the Turkish culture of history teachers, who are the implementers of history lessons, forms the problem case of the present study.

Review of the previous studies in national area presented that Durceylan (2003) studied the administrative and cultural values adopted by university administrators, Ercan \& Sığrı (2015) studied the effects of leadership features on cultural values, Mahiroğulları (2005) studied the effects of globalization on Turkish culture, and Arslanoğlu (2005) conducted an evaluation of Turkish values. In the international literature, Granato et al. (1996) studied the effects of cultural values on economic development, Smith et al. (2002) studied the sources of cultural values, Schwartz (1999) studied the theoretical background of cultural values, and Pinney et al. (2000) studied the differences in cultural values between immigrant and non-immigrant families. Additionally, there are other studied on cultural values conducted by Henry (1976), Pollay (1983), Spener (1983), Ohbuchi, Fukushima \& Tedeschi (1999), Kirkman \& Shapiro (2001), Gerardo \& Raymond (2003), Kim \& Omizo (2003).

The purpose of the present research is identifying the cultural values defining Turkish nation from the perspective of history teachers.

\section{METHOD}

The present research is a qualitative research conducted in descriptive survey model. Qualitative research methods, which pull away from the positivist perspective of physical sciences and guide people to the process of questioning/investigation of human sciences with an interpretive paradigm, require a deep and detailed research of the problem case to be investigated (Patton 2002; Glesne, 2012). For data collection and interpretation, phenomenology, which is one of the qualitative research designs, was employed. Phenomenology design focuses on the phenomena that we are aware of in our 
daily lives but don't have a deep insight of. Phenomena can be encountered in various ways, such as the events, experiences, perceptions, tendencies, concepts and cases in the world we live in. However, these encounters don't mean that we fully understand these phenomena. Therefore, phenomenology is a qualitative research design that aims at describing the ideas, judgements and experiences of people, who encounter phenomena in their daily lives but don't have detailed information about them (Yıldırım \& Şimşek, 2006).

\section{Work group}

The work group of the present research consists of 19 history teachers, who serve in the province of Isparta. The participants were selected through sampling method that is called as 'snowball, chain or network sampling'. Demographic data of the teachers, who participated in the present research, were presented below:

Table 1

Personal Features of The Participants

\begin{tabular}{lllll}
\hline Gender & \multicolumn{3}{l}{ Male } & Female \\
\cline { 2 - 5 } & 10 & $30-39$ & 9 & 50 and more \\
\hline Age & $20-29$ & 6 & $40-49$ & 3 \\
\cline { 2 - 5 } & 2 & $6-10$ years & $11-15$ years & 16 years and more \\
\hline Length of & $0-5$ years & 5 & 8 & 5 \\
service & 1 & Anatolian & Social Sciences & Vocational and technical \\
\hline Type of high & Science & 10 & 2 & 6 \\
\hline
\end{tabular}

\section{Data Collection Tools}

Semi-structured interview technique was used to collect data. Semi-structured questions were used as they enable the fast coding and analysis of data, and comparison of similarities and differences between the data provided by the participants (Çepni, 2005; Büyüköztürk et al., 2008). A draft interview form including six questions was developed by the researchers. Then, one of these items was excluded from the form, and the final form including five items was obtained. The questions asked to the participants are as follows:

1- What do you understand of the concept of culture? How do you define "culture"?

2- What does culture mean for a society?

3- What do you think is the first and most important of cultural values specific to Turkish culture? Why?

4- Can you list other four cultural values reflecting Turkish nation in order of priorities?

5- Do you believe Turkish nation protects their values? Why? 


\section{Data Analysis}

Descriptive analysis and content analysis techniques were adopted to analyze data, and the findings were quantified when appropriate and needed (using numbers). Quantitative expressions can be used to clarify the analysis of qualitative findings, and to increase the reliability (Yıldırım \& Şimşek, 2006: 178).

During the content analysis process, first "coding in accordance with the concepts deduced from the data" was done. This type of coding is mostly valid for researches on the subjects with non-theoretical basis (Yıldırım and Şimşek, 2006). Content analysis enables the revealing of latent content instead of easily captured, clearly presented and perceived content. On the other hand, content analysis can be done via different techniques. These are frequency analysis, categorical analysis, evaluative analysis and contingency or relational analysis. Categorical analysis technique used in the present research refers to the splitting a certain message to units first, then grouping of these units in accordance with certain criteria. The categories should be homogenous, distinguishing, objective, holistic, expedient and meaningful (Bilgin, 2006: 19).

The coding of the data obtained from the interviews conducted for the present research was done by conceptualization, considering the words, sentences and paragraphs. The codes presenting the similarities were gathered and this way thematic coding was done and draft themes were created. Obtained data were gathered under these themes, and presented with "direct quotations.

\section{FINDINGS}

In the present research, the purpose of which is identifying the cultural values defining Turkish nation from the perspectives of history teachers, first general ideas were revealed, then interesting expressions were presented with direct quotations. Findings obtained in the context of sub-objectives were presented respectively in the tables below.

Findings for the first question (What do you understand of the concept of culture? How do you define "culture"?) 
Table 2

The Ways of History Teachers Defining Culture

\begin{tabular}{|c|c|}
\hline Category & Components \\
\hline \multirow{6}{*}{$\begin{array}{l}\text { Culture as a } \\
\text { tool to reflect } \\
\text { past }\end{array}$} & Historical accumulation brought by a society from past \\
\hline & Accumulation coming from past \\
\hline & Everything that belongs to past \\
\hline & Society's savings \\
\hline & Traditions \\
\hline & Traditions our society has \\
\hline \multirow{6}{*}{$\begin{array}{l}\text { Culture defined } \\
\text { as a value }\end{array}$} & Values of the nation \\
\hline & Our present values \\
\hline & A nation's all moral and material values \\
\hline & The whole of values transferred from period to period \\
\hline & All of our existing values \\
\hline & The whole of moral and material values carried by generations of a society \\
\hline \multirow{3}{*}{$\begin{array}{l}\text { Culture as an } \\
\text { element of } \\
\text { innovation }\end{array}$} & Moral and material values produced by humans \\
\hline & Civilization \\
\hline & Self-development, awareness of environment \\
\hline \multirow{4}{*}{$\begin{array}{l}\text { Culture as a } \\
\text { perspective }\end{array}$} & Everything about life \\
\hline & $\begin{array}{l}\text { Defined as universal and local, national culture should develop and } \\
\text { integrate to universal values }\end{array}$ \\
\hline & Perspective and richness of how people see event \\
\hline & Social features with the features of the geography \\
\hline
\end{tabular}

As presented in Table 2, history teachers define culture in different ways but they mostly see it as an accumulation brought from past and the value judgements of the society. This indicates the definition of culture is the sum of the features a society has (Kösoğlu, 2009). In essence, culture is a phenomenon that combines past with present. This can be seen as a driving power providing the continuity of the society. The meaning attached to the culture of the society by people is very important for protecting the culture and providing the continuity of the culture (Güvenç, 2010), because, people can reflect the values they care in affective terms on their behaviours more easily.

Findings for the second question (What does culture mean for a society?) 
Table 3

History Teachers' Perspectives of The Importance of Culture for The Society

\begin{tabular}{lll}
\hline Category & Components & Frequency \\
\hline \multirow{3}{*}{ As a symbol of unity and solidarity } & A must & 1 \\
\cline { 2 - 3 } & Essence of society & 1 \\
\cline { 2 - 3 } & Driving power & 4 \\
\hline \multirow{2}{*}{ As a phenomenon of feeding on past } & The whole of values of the society & 1 \\
\cline { 2 - 3 } & Past of the society & 1 \\
\hline \multirow{3}{*}{ As a tool of reflecting the society } & Unenacted rules & 1 \\
\cline { 2 - 3 } & Independence & 1 \\
\cline { 2 - 3 } & Nothing of society & 3 \\
\cline { 2 - 3 } & Modernization & 4 \\
\cline { 2 - 3 } & Life style & Mirror of society \\
\cline { 2 - 3 } & &
\end{tabular}

As presented in Table 3, history teachers think that culture has an important place in the society, culture must be studied in order to know a society and culture has a key role for the survival of the society. Especially, history teachers' considering culture as the mirror $(n=4)$, driving power $(n=4)$ and life style $(n=3)$ of society shows how important the culture is for a society. Since culture has a important role in providing continuity of societies, the meaning attached to culture is of significance (Yanık, 2013). As the past of them must be studied to know a person, similarly, the past, namely the culture of a society must be studied to know that culture (Kincal, 2015).

Findings for the third question (What do you think is the first and most important of cultural values specific to Turkish culture? Why?) 
Table 4

History Teachers' Perspective of The Cultural Value That Best Reflects Turkish Nation

\begin{tabular}{llll}
\hline Category & Cultural value & Frequency & Reason \\
\hline \multirow{2}{*}{$\begin{array}{l}\text { Values of } \\
\text { universal value }\end{array}$} & Helpfulness & 1 & Our genes \\
\cline { 2 - 4 } $\begin{array}{l}\text { Values forming } \\
\text { with social } \\
\text { environment }\end{array}$ & Tolerance & 1 & A tradition coming from past \\
\cline { 2 - 4 } & Love & 1 & We have a feeling for everything \\
\cline { 2 - 4 } & Life style & 1 & We can't be ourselves \\
\cline { 2 - 4 } & Condemning & 1 & We're different in every way \\
\cline { 2 - 4 } & Patriotism & 4 & Our conservative structure \\
\cline { 2 - 4 } $\begin{array}{l}\text { Values receiving } \\
\text { their essence from } \\
\text { past }\end{array}$ & Hospitality & 2 & A teaching from the family \\
\cline { 2 - 4 } & Loyalty & 1 & $\begin{array}{l}\text { Our being benevolent } \\
\text { very strong }\end{array}$ \\
\cline { 2 - 4 } & Heroism & 1 & $\begin{array}{l}\text { We survived throughout the } \\
\text { history with this }\end{array}$ \\
\cline { 2 - 4 } & Language & 1 & The way to protect culture \\
\cline { 2 - 4 } & Family structure & 1 & $\begin{array}{l}\text { We have a protective structure } \\
\text { and are loyal to each other }\end{array}$ \\
\cline { 2 - 4 } & Wedding ceremony & 1 & $\begin{array}{l}\text { The importance attached to } \\
\text { family }\end{array}$ \\
\hline
\end{tabular}

As presented in Table 4, according to history teachers' perspectives, among the most important values that sustain and reflect Turkish culture are patriotism $(n=4)$, respect to elders $(n=2)$ and hospitality $(n=2)$. This indicates that Turks have a strong feeling of protecting their motherland and human values. Additionally, it can be seen that independence has an important place in Turkish culture. The reason for this was expressed as that the sense of patriotism is inherited to next generation through our genes (Kluckhohn, 1951, cited in: Çukur, 2007; Kafal1, 1999). Every society exist and distinguishes from other societies with its values coming from past. Especially, the prototype values that are adopted and accepted by everyone have an important place in presenting a society. Thus, the values presented in the table above are the values that rise to prominence as the tools in presenting the Turkish culture.

Findings for the fourth question (Can you list other four cultural values reflecting Turkish nation in order of priorities?) 
Table 5

History Teachers' Perspectives of The Cultural Values That Are Unique to Turkish Nation

\begin{tabular}{|c|c|c|}
\hline Category & Cultural value & Frequency \\
\hline \multirow{13}{*}{ National values } & Food culture & 10 \\
\hline & Henna & 3 \\
\hline & Family structure & 3 \\
\hline & Clothing & 2 \\
\hline & Independence & 2 \\
\hline & Respect to ancestors & 2 \\
\hline & Language & 1 \\
\hline & Passion & 1 \\
\hline & Tent & 1 \\
\hline & Soldier send-off & 1 \\
\hline & Bravery & 1 \\
\hline & Javelin throw & 1 \\
\hline & Soldier wedding & 1 \\
\hline \multirow{17}{*}{ Social values } & Hospitality & 9 \\
\hline & Wedding ceremony & 7 \\
\hline & Censure & 3 \\
\hline & Kissing hands & 2 \\
\hline & Friendliness & 2 \\
\hline & Unity and solidarity & 2 \\
\hline & Life style & 1 \\
\hline & Army & 1 \\
\hline & Gathering in Bairams & 1 \\
\hline & Neighbourliness & 1 \\
\hline & Laziness & 1 \\
\hline & Effervescing & 1 \\
\hline & Valour & 1 \\
\hline & Self-indulgence & 1 \\
\hline & What would other people think & 1 \\
\hline & Advice & 1 \\
\hline & Pressure & 1 \\
\hline \multirow{6}{*}{ Religious values } & Love for religion & 3 \\
\hline & Morals & 1 \\
\hline & Martyrization & 1 \\
\hline & Belief & 1 \\
\hline & Funeral ceremony & 1 \\
\hline & Circumcision & 1 \\
\hline \multirow[t]{4}{*}{ Universal values } & Honesty & 2 \\
\hline & Tolerance & 1 \\
\hline & Virtue & 1 \\
\hline & Mercy & 1 \\
\hline
\end{tabular}


As presented in Table 5, according to history teachers' perspectives, among the most important values that are unique to Turkish culture are food culture $(n=10)$, hospitality $(n=9)$ and wedding ceremony $(n=7)$. This present a different aspect of Turkish culture like hospitality, food and wedding ceremony, besides the commonly adopted values such as patriotism and nationalism. In other words, there are some value-judgements that distinguish Turkish culture from other cultures in social are as well. We can claim that most of the values categorized in the table above are accepted by other researchers, who also categorized values (Rokeach, 1973; Lickona, 1991; Schwartz, 1992; Güngör, 1998; Ercan, 2001; Kale, 2004; Canatan, 2004; Acat \& Aslan, 2012).

Findings for the fifth question (Do you believe Turkish nation protects their values? Why?)

Table 6

History Teachers' Perspectives of Why Turkish Nation Doesn't Protect Their Values

\begin{tabular}{|c|c|c|}
\hline No & Teacher perspective & Reason \\
\hline 1 & Protected & $\begin{array}{l}\text { Due to its general characteristics, they are loyal to values, even } \\
\text { that changes in time }\end{array}$ \\
\hline 2 & Not protected & $\begin{array}{l}\text { There are many things that are against out values, I don't think } \\
\text { measures are taken }\end{array}$ \\
\hline 3 & Partially & Due to external factors \\
\hline 4 & Partially & $\begin{array}{l}\text { Because many states have interests in our geography, the fear to } \\
\text { loose it bonds us }\end{array}$ \\
\hline 5 & Not protected & Corruption \\
\hline 6 & Partially & Because we cannot adopt the western culture completely \\
\hline 7 & Not protected & $\begin{array}{l}\text { There is a problem in transferring between generations, we } \\
\text { loose the essence because this is stereotyped and normative. }\end{array}$ \\
\hline 8 & Not protected & We are society that doesn't even value children \\
\hline 9 & Not protected & $\begin{array}{l}\text { There a lot of people that consider themselves as modern when } \\
\text { they imitate western states either in positive or negative sides }\end{array}$ \\
\hline 10 & Not protected & We can't fish. We buy the fish from others. We seize the day. \\
\hline 11 & Not protected & Wannabes, the society has a tendency for west, superficial \\
\hline 12 & Not protected & $\begin{array}{l}\text { Culture remains in the background as we try to meet our primary } \\
\text { needs }\end{array}$ \\
\hline 13 & Not protected & Replaced by TV and computers \\
\hline 14 & Not protected & Because, we've lost it \\
\hline 15 & Protected & We are still patriots, even little. \\
\hline 16 & Protected & It is tradition \\
\hline 17 & Protected & Because we care about other more than ourselves \\
\hline 18 & Not protected & We are assimilated \\
\hline 19 & Protected & $\begin{array}{l}\text { Even some try to pull away our nation from our values, I believe } \\
\text { we still try to protect it. }\end{array}$ \\
\hline
\end{tabular}

As presented in Table 6, most of the history teachers believe that Turkish culture isn't protected enough. The most important reason of this was expressed as corruption, assimilation, that we emulate the western societies, the media destroys our values, the guiding effect of external forces and we don't take the necessary measures to protect our values. Thus, not protecting a that rich culture, or not trying to protect it means trying to 
destroy the past in some way. The societies that have left a trace in the history are the ones that protected their culture and values. Accordingly, every individual should carry the mission of protecting the values and culture of the society as a member of that society.

\section{CONCLUSION AND DISCUSSION}

Culture, as a process of accumulation and formation, is one of the elements that provide continuity of a society. Culture not only guarantees the future of a society, but also enables people living together in a more conscious way (Ülken, 2008). Similarly, according to the perspectives of history teachers, who participated in the present research, culture is of significance as a symbol of unity and solidarity, the phenomenon of feeding on past and tool of reflecting the society. The most prominent of these was that it is considered as tool of reflecting the society. As people maintain their lives and as a result of their social interaction with other people, they form their life styles. These life styles leave trace as time, place, perception, object, phenomenon, understanding and value (Schwartz, 1992). These traces are kneaded for centuries, become traditions and then the mirror of the society. Similarly, the history teachers in the present research stated that culture can serve as a mirror in getting to know the characteristics of a society.

Besides seeing culture as a tool of reflecting society, history teachers believe that the most important values belonging to Turkish culture are the ones that "take their essence from the past". These values that best reflect the Turkish nation and are sourced from the past, such as patriotism, respect to elders and hospitality, can be seen as a tool that best reflect Turkish nation and culture (Kafal1, 1999). Every nation has their unique cultural values (Erkenekli, 2013). The most prominent cultural values that distinguish Turkish nation from other nations in cultural terms can be listed as the love and respect for the motherland, elders and other people.

Apart from these, other cultural values that are considered to define Turkish culture and are unique to Turks are; national values (such as food, henna, family structure, clothing and independence), social values (such as wedding ceremony, censure, kissing hands, friendliness, unity and solidarity), religious values (such as love for religion, morals and Martyrization) and universal values (such as honesty, tolerance and virtue) (Ercilasun, 2009). This indicates that Turkish culture has both national and universal values. As long as societies both protect their values and not close themselves to the cultures of other societies in the globalizing world, as they change and develop, they can survive for long years (Koca \& Şimşek, 2011; Küçük, 2006).

Turkish culture has formed a unique culture with its rich geography and the important values it has. It not only has national values, but also has important value judgements in social, human, and universal terms. However, in order to pay the duty of loyalty to the people who tried to form and protect this unique culture (Mahiroğulları, 2005), we need to protect our cultural values. Indeed, the present research showed that Turkish culture has miscellaneous values; however these values are not protected enough. 
In the scope of the present research, which was conducted in order to identify the cultural values defining Turkish nation from the perspectives of history teachers, 19 teachers were interviewed and the following results were obtained in accordance with the findings obtained from these interviews:

History teachers define culture in different ways, however they mostly see it as a tool reflecting the past, values of the society, an element of innovation and perspective of life. The most prominent expression was that culture is a way of reflecting past and value judgements coming from past. This finding indicates that a society is mostly mentioned with its experiences and accumulation coming from past (Kashima \& Kashima, 1999). Accordingly, the culture of a society is a phenomenon that is the sum of everything belonging to that society for centuries, such as experiences, traditions, languages, and religions (Kafesoğlu, 1992).

\section{RECOMMENDATIONS}

This research is limited to history teachers. The sample may be varied by taking the opinions of other teachers into consideration. The research was carried out with the history teachers working in Isparta city center. Cultural differences can be determined by considering other provinces and regions. In order to increase the reliability of data in qualitative research, observation and document analysis techniques can be used as well as interview technique. When preparing the curricula, the results of such investigations may be taken into account by notifying the Ministry of National Education. The school administration can organize activities for students and parents to keep the values of Turkish culture alive or to draw attention to its importance. Culture has an important mission to ensure the continuity of society. In this respect, activities to draw attention to our cultural values and to raise awareness in social sense can be organized. Activities such as poetry, painting, composition, posters, slogans, drama, theater and exhibitions can be organized in order to sustain cultural values in schools. To bring the students together with our cultural values, teachers should take the necessary responsibilities, especially history teachers, and take them to museums, historical places, places representing our traditions and customs

\section{REFERENCES}

Acat, M. B. \& Aslan, M. (2012). Yeni Bir Değer Sinıflaması ve Bu Sınıflamaya Bağlı Olarak Öğrencilere Kazandırılması Gereken Değerler, Kuram ve Uygulamada Eğitim Bilimleri (KUYEB), 12(2),1460-1474.

Arslanoğlu, İ. (2005). Türk değerleri üzerine bir değerlendirme, Felsefe Dünyası Dergisi, 41, 64-77.

Bilgin, N. (2006). Sosyal bilimlerde içerik analizi: teknikler ve örnek çalışmalar, Ankara: Siyasal kitabevi.

Büyüköztürk, Ş., Kılıç E., Akgün, Ö. E., Karadeniz, Ş. \& Demirel, F. (2008). Bilimsel araştırma yöntemleri, Ankara: Pegem Akademi Yayıncılık. 
Canatan, K. (2004). Avrupa Birliği Ülkelerinde Değerler Yönelimi, Değerler Eğitimi Dergisi, 2(7-8), 41-63.

Çepni, S. (2005). Araştırma ve proje çalı̧̧malarına giriş, Trabzon: Üçyol Kültür Merkezi Yayınları.

Çukur, C.Ş. (2007). "Kültürel Süreçleri Nitelemek, Ölçmek ve İliş̧kilendirmek: Karşılaşıtırmalı Kültürel Yaklaşımlar." İçinde: Yönetsel Örgütsel Davranış (37), (Ed: Ramazan Erdem ve Cem Şafak Çukur), Ankara: Türk Psikologlar Derneği.

Durceylan, B. (2003). Üniversite yöneticilerinin benimsedikleri idari ve kültürel değerler: Anadolu ve Osmangazi Üniversiteleri yöneticileri üzerine bir araştırma, Eskişehir Osmangazi Üniversitesi, Sosyal Bilimler Enstitüsü, Eskişehir.

Ercan, İ. (2001). İlköğretim Sosyal Bilgiler Programında Ulusal ve Evrensel Değerler, Yayınlanmamış Yüksek Lisans Tezi, Onsekiz Mart Üniversitesi, Sosyal Bilimler Enstitüsü, Çanakkale

Ercan, Ü. \& Sığrı, Ü. (2015). Kültürel değerlerin liderlik özelliklerine etkisi: Türk ve Amerikalı yöneticiler üzerine bir araştırma, Amme İdaresi Dergisi, 48(3), 95-126.

Ercilasun, A.B. (2009). "Kimlik ve Dil”, Türk Kimliği, (Ed:M.Çağatay Özdemir), İstanbul: Ötüken Neşriyat.

Erkenekli, M. (2013). Toplumsal Kültür Araştırmaları İçin Değer Merkezli Bütünleşik Bir Kültür Modeli Önerisi, Savunma Bilimleri Dergisi, 12 (1), 147-172.

Gerardo, M. \& Raymond, G. (2003). Chun, Kevin M. (Ed); Balls Organista, Pamela (Ed); Marín, Gerardo (Ed), Acculturation: Advances in theory, measurement, and applied research. pp. 83-93, Washington, DC: American Psychological Association.

Glesne, C. (2012). Nitel araştırmaya giriş, (çev. A. Ersoy ve P. Yalçınoğlu), Ankara: Anı yayıncilı.

Granato, J., Inglehart, R. \& Leblang, D. (1996). The effect of cultural values on economic development: theory, hypotheses, and some empirical tests, American Journal of Political Science, 40/3, 607-631.

Güngör, E. (1998). Değerler Psikolojisi Üzerine Araşttrmalar, İstanbul: Ötüken Yayınları

Güvenç, B. (2010). Insan ve Kültür, İstanbul: Boyut Yayınc1lık.

Henry, W. A. (1976). Cultural values do correlate with consumer behaviour, Journal of Marketing Research, 13(2), 121-127.

Kafalı, M. (1999). Anadolu'nun Fethi ve Türkleşmesi, Trabzon: Trabzon Türk Ocakları Yayınları.

Kafesoğlu, İ. (1992). Türk milli kültürü, İstanbul: Boğaziçi Yayınları. 
Kale, N. (2004). Nasıl Bir Değerler Eğitimi, Değerler ve Ĕ̆itimi Uluslararası Seтроzуити, Değerler Eğitimi Merkezi Yayınları, İstanbul.

Kashima, Y \& Kashima, E. (1999). Culture, Connectivism and the Self. Sage

Kıncal, R. Y. (2015). Vatandaşlık bilgisi, Ankara: Nobel Yayınevi.

Kim, B. \& Omizo, M. (2003). Asian cultural values, attitudes toward seeking professional psychological help, and willingness to see a counsellor, The Counseling Psychologist, 31(3), 343-363.

Kirkman, B. L. \& Shapiro, D. L. (2001). The impact of cultural values on job satisfaction and organizational commitment in self-managing work teams: the mediating role of employee resistanc, ACAD MANAGE, 44(3), 557-669.

Koca, F. \& Şimşek, A. (2011). Liselerde Kültürler Arası Bir Uygulama Örneği Olarak Kanada Programı: Tarih Dersleri Üzerine Öğrenci Görüşleri, Kalem Eğitim ve İnsan Bilimleri Dergisi, 1(1), 155-187.

Kösoğlu, N. (2009). Milli Kimlik ve Tezahürleri, Türk Kimliği (Ed:M.Çağatay Özdemir), İstanbul: Ötüken Neşriyat.

Küçük, S. (2006). Kültürler Arası Konumda İki Dilli Öğrenciler İçin Öğretmen Yetiştirme ve Erasmus Program1, AKÜ Sosyal Bilimler Dergisi, 8(1), 231-251.

Lickona, T. (1991). Educating for Character: How our schools can teach respect and responsibility, Newyork: Bantam Books.

Macionis, J. J. (1989). Sociology, New Jersey: Prentice-Hll, INC.

Mahiroğulları, A. (2005). Küreselleşmenin Kültürel Değerler Üzerine Etkisi, Sosyal Siyaset Konferanslart Dergisi, 50(1), 1275-1288

Obuchi, K. I., Fukushima, O. \& Tedeschi, J. (1999). Cultural values in conflict management goal orientation, goal attainment, and tactical decision, Journal of CrossCultural Psychology, 30(1), 51-71.

Parekh, B. (2002). Çok kültürlülüğ̈̈ yeniden düşünmek, (çev. Bilge Tanrıseven). Ankara: Phoenix yayınevi.

Patton, M. Q. (2002). Qualitative research \& evaluation methods, Thousand Oaks, CA: Sage.

Pinney, J. S., Ong, A. \& Madden, T. (2000). Cultural values and intergenerational value discrepancies in immigrant and non-immigrant families, Child Development, 71(2), 528539 .

Pollay, R. W. (1983). Measuring the cultural values manifest in advertising, Current Issues and Research in Advertising, 6(1), 71-92.

Rokeach, M. (1973). The nature of human values, New York: The Free Press 
Schwartz, S. H. (1992). Universals in the content and structure of values: Theoretical advances and emprical tests in 20 countries, Advances in Experimental Social Psychology, 25,1-65.

Schwartz, S. (1999). A theory of cultural values and some implications for work, Applied Psychology: An International Review, 48(1), 23-47.

Smith, P., Peterson, M. \& Schwartz, S. (2002). Cultural values, sources of guidance, and their relevance to managerial behaviour, Journal of Cross-Cultural Psychology, 33(2), 188-208.

Spencer, M. B. (1983). Children's cultural values and parental child rearing strategies, Developmental Review, 3(4), 351-370.

Ulusoy, K. (2005). Tarih dersinde ahlaki değerlerin aktarımı, bir okuma parçası örneği, Milli Eğitim,168, 126-133.

Ulusoy, K. \& Dilmaç, B. (2015). Değerler eğitimi, Ankara: Pegem Akademi.

Ülken, H.Z. (2008). Millet ve Tarih Şuuru, İstanbul: Türkiye İş Bankası Yayınları

Yanık, C. (2013). Dünyada ve Türkiye'de çokkültürlülük, Bursa: Sentez Yayıncılık

Yıldırım, A. \& Şimşek, H. (2006). Sosyal bilimlerde nitel araştırma yöntemleri, Ankara: Seçkin Yayınları. 